\title{
Mercédès' Endeavour
}

\author{
Gary Ansdell ${ }^{1}$ * \\ 1 Independent music therapy practioner and scholar, United Kingdom, \\ *garyansdell@gmail.com
}

Published: 1 July 2018

[Editorial note: This piece is a more detailed version of an address given at Mercédès' funeral on 25 June 2018. It is also being published in the British Association of Music Therapy newsletter, Leading Note].

About six weeks ago I was sitting with Mercédès and she said:

"I want you to talk at my funeral ... about my work ... ." She paused ...

"But it's not just work, because it's been my life too ... .". And after a further pause she came up with the right word - "It's endeavour - that's it!"

Endeavour - what we strive for, struggle with, dedicate our energy, and attention to

Actually, endeavour was everything in Mercédès' life apart from her equal dedication to family and friends ...

"But don't just give them a list of achievements ... BORING!... and don't gone on longer than 4 minutes!".

So these were my orders (not for the first time!). A tall order ... . How the hell to summarise Mercédès' endeavour of 40 years in 4 minutes?

So I threw back the challenge: "We've got to find the nub of it all ... what image comes to mind?"

Through the fog of the morphine this came quick as a flash:

"I'm at home in Joburg in 1976 ... I'm practising Bach on the piano, and close by Soweto is burning. My sister and her boyfriend are out there manning the barricades ... whilst I'm in here practising Bach. I'm feeling guilty, useless, but at that time activism isn't my thing".

Here's the nub of the next 40 years' endeavour: a powerful but simple question Mercédès asked herself:

What's the use of music and the arts in times and situations of trouble, challenge, stress, struggle?

Mercédès lived this question through her endeavour: training as a music therapist in London, doing music therapy with so many people, researching a pioneering doctoral thesis, writing and editing 7 books and endless articles, talking at endless conferences ... Then setting up the first music therapy training in Africa, battling on academic committees, training music therapists, supervising doctoral students in London ... . painting pictures, doing conflict transformation work in the Lebanon recently ... . I could go on and on ... [Oh dear, this is the boring list of achievements I was told not to do!].

So back to the nub of it: What was the truth that she pursued through all this endeavour? ("Truths, plural, please dear!" I was corrected).

Mercédès cared about ideas, so we should also care for her ideas as we remember her now. These developed directly from her practical work, which we could divide into two phases: 
The first phase begins with her early work as a music therapist in Scotland when she worked with people with chronic schizophrenia who seldom communicated verbally and seemed so isolated. But when Mercédès played music with them she found how much they actually communicated of themselves musically. Did their music sound flat or florid? Quiet or loud? Smooth or rough? Bursting with energy or fading away?

A lightbulb moment came for Mercédès when she discovered the new theory about non-verbal communication the developmental psychologists Colwyn Trevarthen and Daniel Stern were developing then. They were studying early communication between mother and infant and seeing just how musical it is ... .whilst Mercédès was finding how her patients with schizophrenia were reverting to nonverbal musical communication when words had failed them.

Mercédès was soon studying with Colwyn Trevarthen for her doctoral research and developed her own theory of non-verbal communication through music - which she called 'dynamic form'. We communicate ourselves musically - through feelingful forms that are dynamic, ever-changing. As someone once said, music sounds how emotions feel - both within and between us. The mature version of this theory is now known as communicative musicality.

The therapy lies in how client and therapist read each other's dynamic forms through musicking and then create a shared musically dynamic form, which helps freeup people and their expressive communication.

Mercédès' practical and theoretical work in this area was ground-breaking and led to a output of articles, books, conference presentations, and teaching. Music therapists still say to me that only after reading her books did they understand for the first time what they were really doing!

$* * *$

But this was just Phase One of her innovation! Fast-forward now to Phase Two, when Mercédès has moved back to South Africa in the 1990s and is leading the first music therapy training programme in Africa at Pretoria University. Here the traditional Western model of music therapy jars against the culture and context there, and this inspires Mercédès to get thinking again and tinkering with her ideas. By this time she and I are joyfully thinking-together over early email systems ... . asking some thorny questions:

Is the idea of communicative musicality enough of a guide for doing music therapy in Africa? Is the Western practice of the private therapy room for an individual client enough? In short our answer was 'no' to both of these questions, and from our thinking - along with an international group of music therapists - we eventually come up with a new approach: community music therapy, which actively links the private and public, the intimate and the performative within music therapy. This idea has been doing quite well internationally over the last nearly 20 years, and Mercédès was a crucial architect of this significant shift of thinking.

The connection between Mercédès early and late work is that you need the craft and knowledge of how to cultivate musical intimacy in order to help create broader musical community. The two phases of her endeavour join together the continuum of how music can help people in times of trouble ...

I hope you see now how Mercédès found an answer to that question that had bothered her when playing Bach whilst Soweto was burning - What's the use of music and the arts in times and situations of trouble, challenge, stress, struggle?

She could say with confidence: Yes, music and the arts are important in times of trouble: in traditional, or more radical forms of therapy; in social and political action; in the everyday life of any community. Mercédès' work helps to explain how this is so

Music and the arts stir us up, shift us around, challenge us, unstick us. When we get static they're dynamic; when we get too fluid they offer form; when we get isolated they join us together; when we get too earth-bound they lift us; when we get too pompous they remind us that fun and joy are crucial. 
But this truth reaches further than just talk about the goodness of the arts. It also says something important about our lives, for we are all 'dynamic forms': we quicken, we come together as people, we transform constantly, we fall apart, we still.

Mercédès was a dynamic form if there ever was one! Her favourite words: energy, conbust, fizz ... her main put-downs: dull, boring, limp, no energy ... or that non-verbal flick of the wrist many of us know well ... meaning anything from "who knows?" to "piss off!"

She was often energetic, sometimes spiky, but also gentle and smooth, intimate, and social. She was usually ready to stir up and disrupt ... but also to elegantly and skilfully put things together and smooth things out ... to coax the best out of people or situations ... to nurture courage, boldness, faith, love ... .

The fruit of Mercédès' endeavour is becoming clear and is our gift from her: an influential legacy of thinking and practice for music therapy and beyond music therapy ... . but also a life-lesson for us all:

Stir it up ... get moving ... be bold... share your energy ... be naughty sometimes and shake things up ... . but also ... create beauty together, party, believe in people, cherish each other ...

And also ... know when to leave, know how to let go - with dignity and grace.

Good Endeavour, Mercedes! 